\title{
DESIGNING A ROUTER REDUCTION SYSTEM USING HOT STANDBY ROUTER PROTOCOL METHOD FOR BACKUP LINK IN DITJEN PPKL
}

\author{
Andri Nuki Baskoro1; Anton²; Puji Astuti ${ }^{3}$ \\ Informatics Engineering \\ STMIK Nusa Mandiri \\ www.nusamandiri.ac.id \\ andrinukibaskoro@gmail.com; anton@nusamandiri.ac.id; puji.pat@nusamandiri.ac.id
}

\begin{abstract}
Computer networks play an important role in data communication at companies or government institutions to support them in terms of work. In this case, the authors conducted observational research and direct interviews with IT staff at the Ditjen PPKL Control about how the network operates in that place. Routers have a very important role in data communication and connecting different networks, so a router reduction system is needed as a solution to minimize failures on the network or these devices. The network topology in each office or government agency is different, which makes the problems in each government office or agency different. Based on the research that has been done, the network of the Ditjen PPKL often experiences a link down which causes disconnection of the internet connection and hinders the productivity of staff. So a router redundancy system is needed to maintain network availability, such as the Hot Standby Router Protocol (HSRP) which has two lines, one as the mainline and the other as a backup if the mainline is down. That way network availability will always be maintained without having to wait for the IT staff to do troubleshooting if there is a network failure. The result of this research is to provide maintained network availability. Even if a link goes down, the network will automatically return to normal.
\end{abstract}

Keywords: Router Redundancy, HSRP, Backup.

\begin{abstract}
Abstrak-Jaringan komputer memegang peranan penting dalam komunikasi data pada perusahaan ataupun institusi pemerintah agar dapat menunjang dalam hal pekerjaan. Dalam hal ini, penulis melakukan penelitian observasi dan wawancara langsung pada staff IT Ditjen Pengendalian Pencemaran dan Kerusakan Lingkungan tentang bagaimana jaringan berjalan di tempat tersebut. Router memiliki peran yang sangat penting untuk komunikasi data dan menghubungkan network berbeda, sehingga diperlukan sistem redundasi router sebagai solusi untuk meminimalisir
\end{abstract}

kegagalan pada jaringan ataupun pada perangkat tersebut. Topologi jaringan pada setiap kantor maupun instansi pemerintah berbeda-beda yang menjadikan permasalahan pada setiap kantor atau instansi pemerintah pun berbeda pula. Berdasarkan penelitian yang telah dilakukan, pada jaringan Ditjen Pengendalian Pencemaran dan Kerusakan Lingkungan sering mengalami link down yang menyebabkan terputusnya koneksi internet dan menghambat produktifitas dari para staff. Sehingga dibutuhkan sistem redundansi router untuk menjaga ketersedian jaringan penulis menggunakan metode yaitu Hot Standby Router Protocol (HSRP) yang memiliki dua jalur, satu jalur sebagai jalur utama dan yang lain sebagai backup apabila jalur utama mengalami down. Dengan begitu ketersediaan jaringan akan selalu terjaga tanpa harus menunggu Staff IT melakukan troubleshooting apabila terjadi kegagalan pada jaringan. Hasil dari penelitian ini adalah memberikan ketersediaan jaringan yang terjaga. Meskipun salah satu link mengalami down, jaringan akan kembali normal secara otomatis.

Kata Kunci: Redundansi Router, HSRP, Backup.

\section{INTRODUCTION}

Computer network plays an important role in data communication in companies and government institutions to support in terms of work. In this case, the Ditjen PPKL depends on the network computer, so the network administrator in such a place must provide the computer network as efficiently as possible to maintain the stability of the data communication. But, the problems that can occur on the network due to link failure and device failure. The Router has a very important role in data communications and linking networks of different so that the required system redundancy router as a solution to minimize the failure on the network or the device. 
A network system that can be used to perform a backup and to anticipate the disruption that occurs is a system of network-based redundancy (Firmansyah, Wahyudi, M \& Rachmat, 2018). To solve the problem, the protocol redundancy can substantially do it (Anwar et al., 2019). The protocol is useful to keep the network always in ON condition with how to provide path redundancy is First Hop Redundancy Protocol (FHRP) (Suprijatmono \& Siswadi, 2019). FHRP includes various types of protocols, however, the three protocols are the main Hot Standby Router Protocol (HSRP), Virtual Router Redundancy Protocol (VRRP), and Gateway Load Balancing Protocol (GLBP) (Rahman et al., 2017). VRRP has excess rapid failover link from master to backup, however a little long in the failover link from backup to master (Firmansyah, Wahyudi, M \& Rachmat, 2018). Whereas GLBP can load balance or load but has a throughput that is small enough so that the effect of packet loss or delay in the Quality of Services (QoS) (Akmaludin et al., 2019).

That is one of the redundancy protocols, standard Cisco Hot Standby Router Protocol (HSRP) where the concept is a router that takes over the task automatically if the main router is down (Pratama, 2019). With two pieces of a cisco router acting as a router the primary and the standby, which has different paths towards the ISP and has an IP LAN that is in the same network. Both routers exchange information to determine the status of each router, so that when one router is experiencing down then it can be taken over by other routers (Pratama, 2019). And from the research (Akmaludin et al., 2019; Firmansyah, Wahyudi, M \& Rachmat, 2018) HSRP is the right solution to provide backup links with failover as well as Quality of Services (QoS) in maintaining network availability, however, have a failover the master to the backups a little longer than VRRP. HSRP also serves to replace the gateway in case of down on one of the devices (Sulaiman et al., 2015).

The problems that occur on a computer network in the Ditjen PPKL are the Link down can take place in a day and fix the back chain does a restart of the device, and reduce the productivity of the staff working (Pracasitaram et al., 2019). View of the existing problems, for that system redundancy, is needed to maintain the availability of network and data communication (Geraldi et al., 2020) at the Ditjen PPKL.

The problems that occur on the network will be different in every company and institution due to the topology at each place there is a difference. To reduce the problems that occur on a computer network required the design of a computer network that is effective in dealing with these problems (Haryoyudhanto et al., 2020) and Quality of Services (QoS) will be constrained if a failure occurs in a network. Then the availability of computer networks is indispensable to keep the stability of the network, so requires a system $\mathrm{Hot}$ Standby Router Protocol (HSRP) (Purwanto \& Risnanto, 2018). So IT staff can do the troubleshooting, but the network is still running normally (Fadhilah et al., 2020).

The purpose of this research is to ensure the sustainability of the network with Hot Standby Router Protocol (HSRP) although the damage occurs in the device the main router (Udhayamoorthi et al., 2015) and add to the efficiency in the availability of a computer network.

\section{MATERIALS AND METHODS}

Data collection methods the author do the following:

a. Observation

Namely the search for and collect information about the network and the constraints that are often faced with how to record and observe directly how the network goes.

b. Interview

The author conducted interviews with the IT staff of the Ditjen PPKL the Environment to get information in detail.

c. The Study of Literature

By reading and studying the materials related to the problems that exist as a reference and benchmark. The material is in the form of scientific journals, literature books, and articles.

There's some point in the analysis of research in, (Pratama, 2019), among others:

a. Needs Analysis

In the design to make the system redundancy router use the features of the Hot Standby Router Protocol (HSRP), the author requires software Cisco Packet Tracer as a medium.

b. Design

Designed the concept of the network a Hot Router Protocol Standby (HRRP) to create schema, topology, and simulation using Software Cisco.

c. Testing

In this stage, the network is tested with the connectivity.

d. Implementation

The network that has been created in the form of simulation testing will be conducted and reevaluation.

As for the draft application which the author has made the following: 


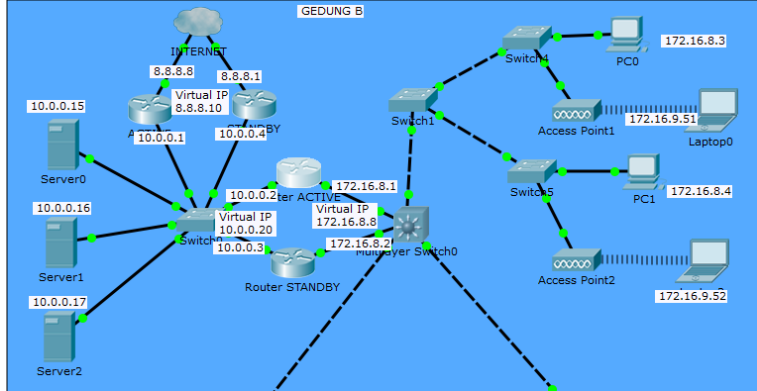

Source: (Baskoro et al., 2020)

Figure 1. The Draft Application

In Figure 1. in the above, the multilayer switch serves as the core of the spread of the connection to the airport building which is accepted by the switch that the other. The draft application which the authors propose is to create a system of redundancy the router using the method Hot Standby Router Protocol (HSRP). A router that has been configured using HSRP consists of a router is the active router and the standby that will take over the link automatically if the router is active failed (Pratama, 2019). HSRP has a virtual router that will serve as a gateway (Kumar \& Vasanth, 2017). Hot Standby Router Protocol (HSRP) has a failover in maintaining network availability.

\section{RESULTS AND DISCUSSION}

In the network architecture running on the Ditjen PPKL are known that have multiple servers in the office such as the database server and application server. Then for internet service, the Ditjen PPKL is also using the Internet Service Provider (ISP).

\section{The Scheme of The Network Running}

The scheme of the network contained in the Ditjen PPKL is as follows:

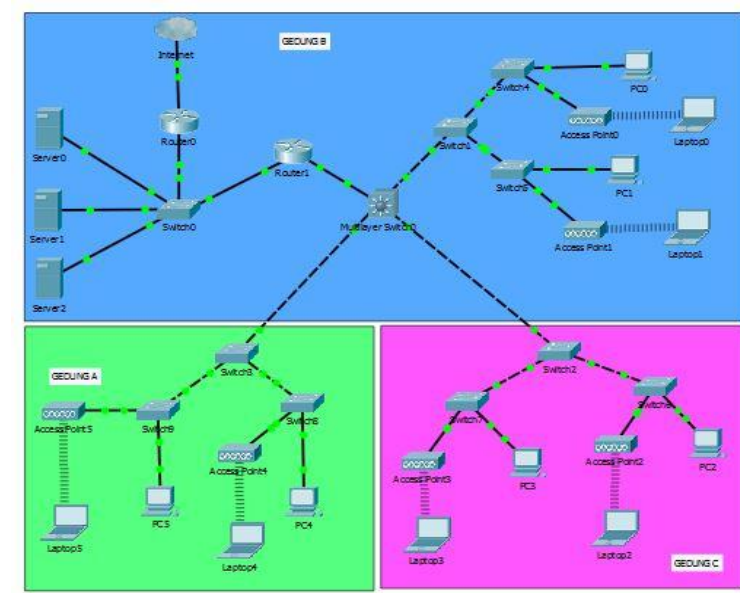

Source: (Baskoro et al., 2020)

Figure 2. The Scheme Of The Network Running
Figure 2. is the scheme of the network of the Ditjen PPKL that is located in Jl. DI. Panjaitan, Kav. 24 Kebon Nanas, Jakarta 13410. Of the network scheme above can be seen that such buildings are connected. For need speed data access, then Ditjen PPKL using Fiber Optic cable (FO) to connect, the connection between buildings. While the connection is in one building using UTP cat6 cable as a line to connect it. Then there are three servers, namely, server a magpie, wren, and staffing. While the user that there are approximately 300 users, so the office is using the IP address to class $B$ with Prefix /23 so not too much IP which is not used.

\section{Scheme Network Proposal}

The following is the scheme of the network that the author made:

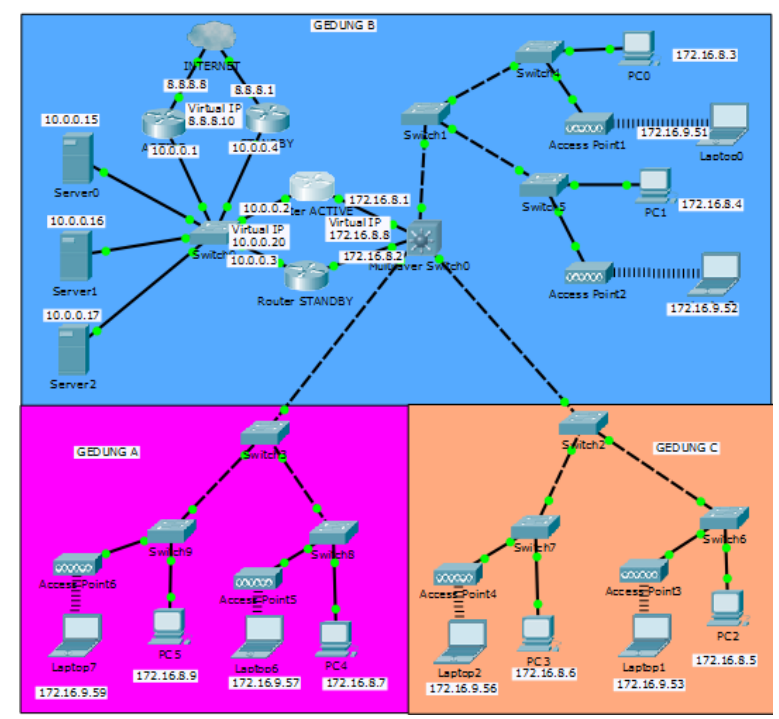

Source: (Baskoro et al., 2020)

Figure 3. Scheme Network Proposal

Figure 3 scheme of the network above is a network scheme that the author made as a proposal. The author does not perform a topology change in the network scheme that is already there. IP Address used on the network above, for a free computer using an IP Address Class B with prefix /23, then for the IP Address of the ISP using the Public IP Address. The User who is connected via a cable, using the IP Address static, while connected through Wireless will use IP Address will be obtained automatically or DHCP. The authors add to the router that will be configured with HSRP so that the network connection is stable. With two routers configured with HSRP, that router is the active router and the standby creates a virtual router that will be used as a gateway. The second IP router within the same network. Because the second router will continue to exchange status information 
from each router. Although both the router and the link towards the ISP is in a normal state, only one router works that router active. The Router the other will be on standby which will soon change its status to active when the router is actively experiencing interference or obstacle.

\section{Network Testing}

\section{a. Network Testing Early}

Testing of the initial network using this topology the network is still running at the Ditjen PPKL.

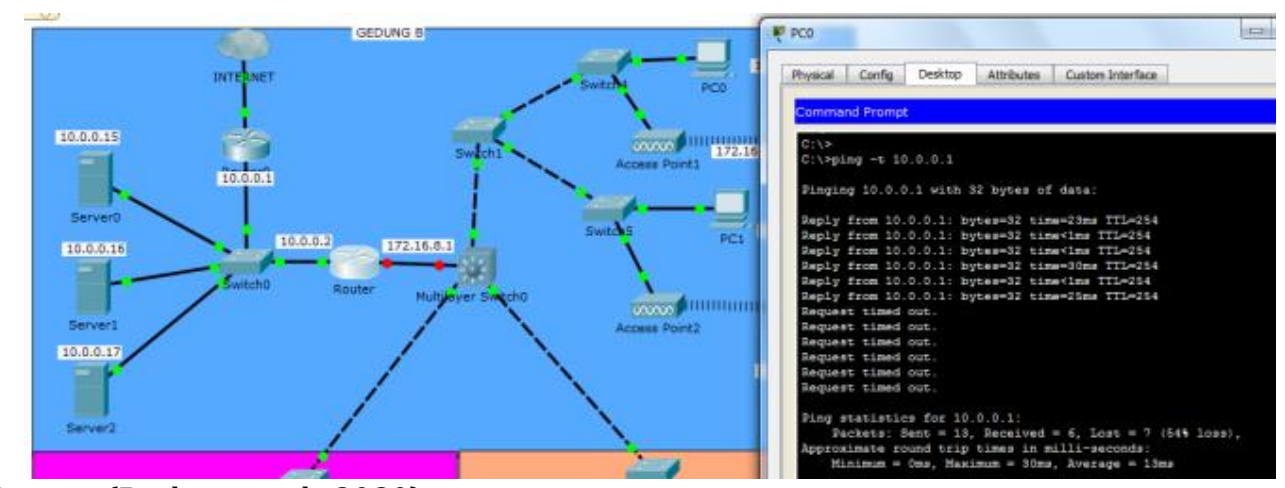

Source: (Baskoro et al., 2020)

Figure 4. Network Testing Early

In Figure 4. network running using only one fruit of the router. Testing is done from PC0 to a router ISP with how to perform the ping command continuously, which then carried out the test link down. When the user wants to access the internet or the server, then going the link down, or disruption to the router, then the computer network instantly paralyzed and requires waiting for IT Support to do the troubleshooting that is done a restart of the device which caused only the availability of the link as the mainline and there is no link standby as a backup.

\section{b. Testing The Network End}

Testing the final network uses a network topology proposal that has been the author of the design.

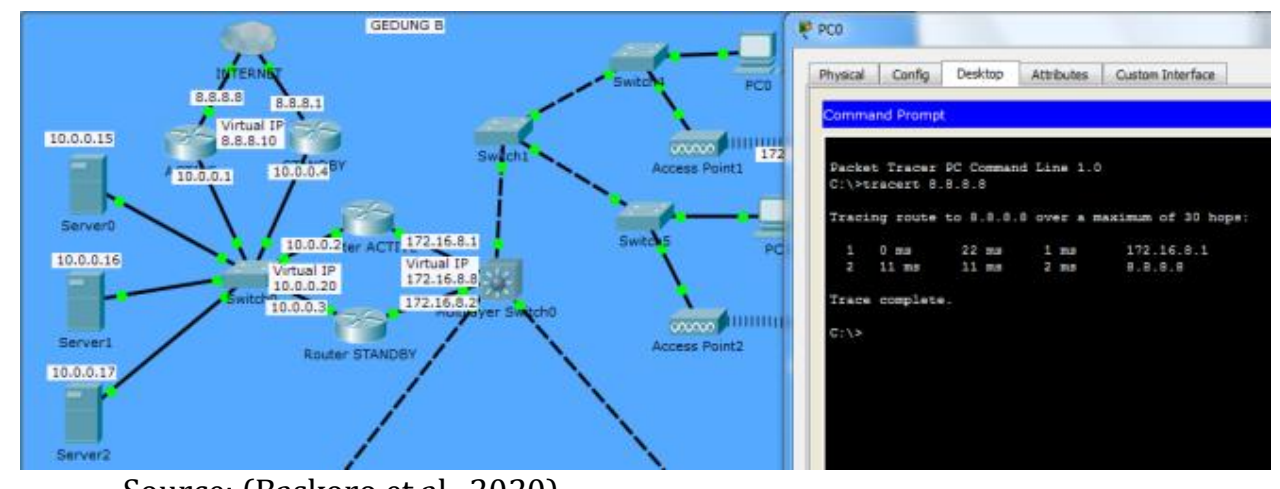

Source: (Baskoro et al., 2020)

Figure 5. Trace

1. Configurasi HSRP on router active

Active(config) \#interface fastethernet $1 / 0$ Active(config-if) \#ip address 172.16.8.1 255.255 .254 .0

Active(config-if) \#standby 1 ip 172.16.8.8 Active(config-if) \#standby 1 preempt

Active(config-if) \#standby 1 priority 110

Active(config-if) \#no sh

Active (config-if) \#exit

Active(config) \#interface fastethernet $0 / 0$

Active(config-if) \#ip address 10.0.0.2

255.0 .0 .0
Active(config-if) \#standby 2 ip 10.0.0.20 Active(config-if) \#standby 2 preempt Active(config-if) \#no sh

\section{Configuration HSRP on router standby}

Standby (config) \#interface fastEthernet $1 / 0$
Standby (config-if) \#ip address 172.16 .8 .2
255.255 .254 .0
Standby (config-if) \#standby 1 ip 172.16 .8 .8
Standby (config-if) \#standby 1 preempt
Standby (config-if) \#no sh


Standby (config-if) \#exit

Standby (config)\#interface fastEthernet $0 / 0$

Standby (config-if)\#ip address 10.0.0.3

255.255 .254 .0

Standby (config-if) \#standby 2 ip 10.0.0.20

Standby (config-if) \#standby 2 preempt

Standby (config-if) \#standby 2 priority 110

Standby (config-if) \#no sh

Standby (config-if) \#exit

In figure 5 the topology above, all devices are already connected and configured by the draft that has been made. The author adds one fruit of the router to function as a router backup. Then the second router is configured with Hot Standby
Router Protocol (HSRP) as the above configuration that forms a virtual IP that will be used as a gateway for each user connected. Figure 4 is a test that is performed using Tracert from PC0 to router distributing the internet and aims to show the route which bypassed the package until it reaches the destination and from the pictures, it can be known that the results of the Tracert command are a route that bypassed the package through router active (172.16.8.1) which became the mainline, then up on purpose.
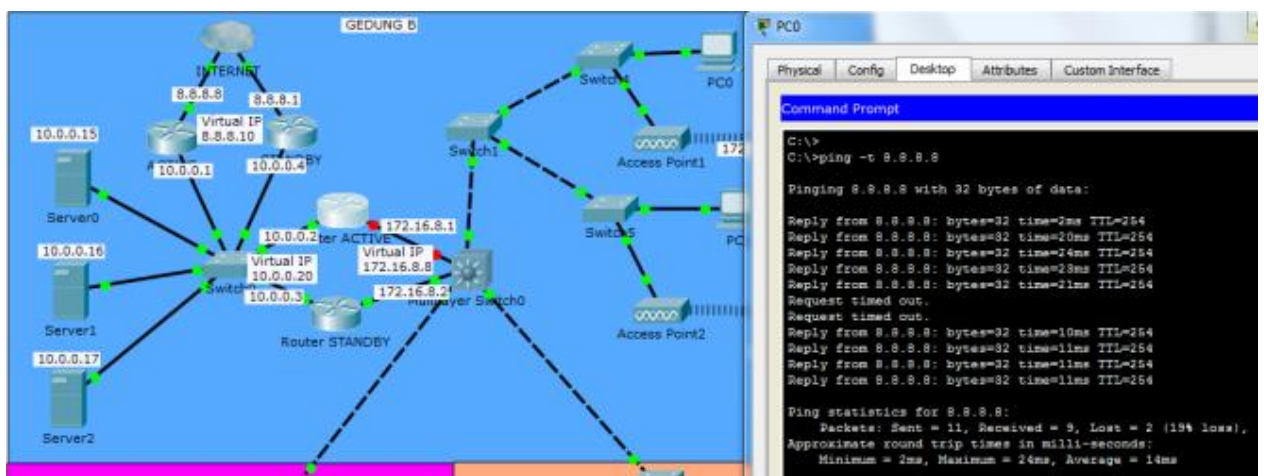

Source: (Baskoro et al., 2020)

Figure 6. Testing The Termination Of The Link

Figure 6. the above is the testing of the disconnection of the link that aims to see whether the network will remain down or will keep running normally. From the image above it can be seen that the network was disconnected then back to normal because when the mainline or router active that are experiencing down will be directly transferred on the backup path or router standby so the network will continue to run normally.

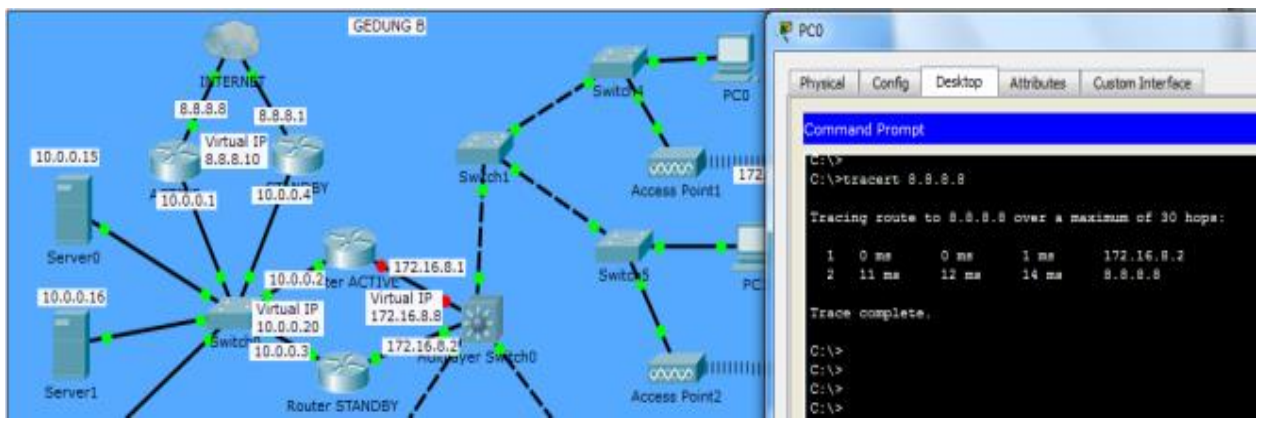

Source: Baskoro et al (2020)

Figure 7. Traceroute

Figure 7 above is a testing route after a Link down on the mainline. The image above shows that the router is on standby to take over the mainline what happens link down can be seen from the path that bypassed that router standby (172.16.8.2) so the package can continue to move without constraints, although the mainline has down. And if the main router is active again, then the line automatically moved back on the router active such as the displacement path of the router is active to the router standby.

\section{CONCLUSION}

After the establishment of the method of Hot Standby Router Protocol (HSRP) as the network proposed in Ditjen PPKL, the authors conclude that with such methods the availability of the internet network will be maintained because the two routers act as a router of the active router and the standby backup network if a failure occurs. Also, in this method, there is a virtual IP that will be used on the LAN network as a gateway. 
With this method each user wants to access the internet or the server, the path will be determined and the paths that will be used as the path to access it. So the possibility of the user can not access the server or the internet will be very small.

\section{REFERENCE}

Akmaludin, A., Mt, A., Masruroh, S. U., \& Sc, M. (2019). Evalusi Kinerja Hot Standby Router Protocol ( HSRP ) dan Gateway Load Balancing Protocol ( GLBP ) Untuk Layanan Video Streaming. CyberSecurity Dan Forensik Digital, 2(1), 43-51.

Anwar, U., Teng, J., Umair, H. A., \& Sikander, A. (2019). Performance analysis and functionality comparison of FHRP protocols. 2019 IEEE 11th International Conference on Communication Software and Networks, ICCSN 2019, 111-115. https://doi.org/10.1109/ICCSN.2019.89053 33

Baskoro, A. N., Anton, A., \& Astuti, P. (2020). Independent Research Final Report: Designing a Router Reduction System Using Hot Standby Router Protocol Method for Backup Link In Ditjen PPKL.

Fadhilah, M. I., Supendar, H., \& Sw, S. (2020). PERANCANGAN BACKUP ROUTER DENGAN METODE HSRP ( HOT STANDBY ROUTER PROTOCOL ). 23(1), 1-10.

Firmansyah, Wahyudi, M \& Rachmat, P. (2018). Analisis Perbandingan Kinerja Jaringan CISCO Virtual Router Redundancy Protocol (VRRP) Dan CISCO Hot Standby Router Protocol (HSRP). Teknik Komputer AMIK BSI Tegal, 1(1), 764-769.

Geraldi, T. E., Wahyuddin, M. I., \& Aningsih, A. (2020). Perancangan Backup Link Menggunakan Metode HSRP (Hot Standby Router Protocol) Dalam Penyediaan Layer-3 Redundansi. Jurnal Media Informatika Budidarma, 4(1), 201-207. https://doi.org/10.30865/mib.v4i1.1873

Haryoyudhanto, H. D., Fitri, I., \& Aningsih, A. (2020). Implementasi Encapsulation Jaringan Redudansi VLAN Menggunakan Metode Hot Standby Router Protocol (HSRP). JOINTECS (Journal of Information Technology and Computer Science), 5(1), 49. https://doi.org/10.31328/jointecs.v5i1.124 7

Kumar, B. I. D., \& Vasanth, G. (2017). Performance
Evaluation of HSRP based reliable Multihomed Network for two Different Applications. International Journal of Innovations \& Advancement in Computer Science IJIACS, 6(8), 92-99.

Pracasitaram, I. G. M. S. B., Sastra, N. P., \& Wirastuti, N. D. (2019). Performansi Jaringan TCP/IP Menggunakan Metode VRRP, HSRP, dan GLBP. Majalah Ilmiah Teknologi Elektro, 18(1), 77. https://doi.org/10.24843/mite.2019.v18i01. p11

Pratama, E. K. (2019). Implementasi Hot Standby Router Protocol Cisco Pada Jaringan Thin Client. Jurnal Akrab Juara, 4(4), 160-168. https://doi.org/10.1017/CB097811074153 24.004

Purwanto, W., \& Risnanto, S. (2018). Implementasi metode hsrp pada bank jawa barat dan banten kantor wilayah i dan kcp simpang dago. Jurnal Infotronik, 3(1), 35-45.

Rahman, Z. U., Mukhtar, S., Khan, S., Khan, R., Ullah, Z., Rashid, R., \& Ahmad, W. (2017). Performance Evaluation of First HOP Redundancy Protocols ( HSRP, VRRP \& GLBP ). J. Appl. Environ. Biol. Sci, 7(3), 268-278.

https://www.researchgate.net/profile/Zia_Ur_Rah man6/publication/319392641_Performance _Evaluation_of_First_HOP_Redundancy_Proto cols_HSRP_VRRP_GLBP/links/59a7b587458 5156873d1d890/Performance-Evaluationof-First-HOP-Redundancy-Protocols-HSRPVRRP-GLBP.pdf

Sulaiman, O. K., Ihwani, M., \& Basri, M. (2015). Model Hierarki Network dengan Menggunakan Spanning Tree Protocol (STP) dan Hot Standby Router Protocol (HSRP). Seminar Sehari Program Pascasarjana Informatika (SENOPATI), 1(1), 42-46.

Suprijatmono, D., \& Siswadi, A. (2019). Implementasi First Hop Redundancy Protocol ( FHRP ) Pada Jaringan Data Untuk Meningkatkan Availibility Pada Pelanggan. Sainstech, 29(2), 50-59.

Udhayamoorthi, M., Mohan, K. S., Karthik, D. S., Dinesh, P. S., \& Senthilkumar, C. (2015). Enhanced Designing Of Network Using Ipv6 Protocol And Enabling Hsrp For Redundancy. International Conference on Soft-Computing and Network Security. 